\title{
Moss mites (Acari, Oribatida) at the edges of bog lakes and pools in Brodnica Lakeland and Orawa-Nowy-Targ Basin (Poland)
}

\author{
ANNA SENICZAK ${ }^{1}$, STANISŁAW SENICZAK ${ }^{2}$, MARCIN MISTRZAK ${ }^{1}$, ANNA NOWICKA ${ }^{1}$ \\ and EWA KRASICKA-KORCZYŃSKA ${ }^{3}$ \\ ${ }^{1}$ Department of Ecology, University of Technology and Life Sciences, Ks. Kordeckiego 20, \\ 85-225 Bydgoszcz, Poland \\ ${ }^{2}$ Department of Zoology, Kazimierz Wielki University, Ossolińskich Av. 12, 85-092 Bydgoszcz, Poland \\ ${ }^{3}$ Department of Botany and Ecology, University of Technology and Life Sciences, Kaliskiego 7, \\ 85-796 Bydgoszcz, Poland \\ Corresponding author: Anna Seniczak, aseniczak@utp.edu.pl
}

(Received on 12 March 2012; Accepted on 17 December 2013)

\begin{abstract}
Moss mites were investigated at the edges of 4 bodies of water located in bogs: 2 lakes in Brodnica Lakeland ( $\mathrm{O}$ and $\mathrm{S}$ ) and 2 pools in Orawa-Nowy-Targ Basin (K and LP). The lakes differed from the pools in most of the analysed physicochemical parameters of water and in plant associations growing at their edges. Consequently, the species richness of Oribatida and their species composition differed between lakes and pools, but the total abundance of mites was similar. Abundance of most species was low, and only 13 had dominance indices $(D)$ exceeding $1 \%$. The acarofauna of both lakes was similar, as most abundant in them was Limnozetes foveolatus $(D>80 \%$ ), and relatively abundant were Hydrozetes longisetosus, Limnozetes ciliatus, Punctoribates sellnicki, and Trhypochthonius nigricans. These species were absent or rare at the edges of pools K and LP. In the pools, differences in species structure of Oribatida were observed. At pool K, Trimalaconothrus maior was most abundant, accompanied by Hydrozetes octosetosus, H. lacustris, and Limnozetes foveolatus. At pool LP, Trimalaconothrus foveolatus was most abundant, which tolerates a wider range of humidity than T. maior; relatively abundant were also T. maior, Hydrozetes lacustris, and several species that were not found in the other bodies of water, including a generalist like Oppiella nova. In this study, Liochthonius furcillatus and Cultroribula berolina were recorded for the first time from Poland.
\end{abstract}

Keywords: Acari, Oribatida, bog, ecology

\section{INTRODUCTION}

Oribatid mites, commonly called the 'moss mites', are very abundant in bog ecosystems (e.g. StrenzKe 1952; Popp 1962, 1970; RAJSKi 1970; BorCARD et al. 1995), where they are important in decomposition of organic matter (KURIKI 2008). They are known as sensitive bioindicators of natural successional changes and anthropogenic influences, like e.g. bog trampling, draining, peat exploitation, or improper forest 
management (reviewed by SENICZAK 2011b). Moreover, knowledge about the ecology of Oribatida from bogs is important for palaeoecological studies and can contribute a lot to interpretation of fossil data (ERICKSON 1988; Solhøy 2001; Erickson \& PlatT 2007; Presthus-Heggen et al. 2010). However, despite the importance of oribatid mites in bogs, knowledge about their ecology is still insufficient and requires more investigations (reviewed by SENICZAK 2011b).

The aim of this study was to compare oribatid communities at the edges of 4 bodies of water located in bogs in Poland.

\section{MATERIAL AND METHODS}

\section{Study area}

Samples were taken from the edges of 4 water bodies located in bog reserves Lake Okonek (O) and Lake Stręszek (S) in Brodnica Lakeland (Pojezierze Brodnickie, in northern Poland), and pools K and LP in unprotected bogs Kaczmarka and Łysa Puścizna, respectively, in Orawa-Nowy-Targ Basin (Kotlina Orawsko-Nowotarska, in southern Poland).

Lake O $\left(53^{\circ} 23^{\prime} 08^{\prime \prime} \mathrm{N}, 19^{\circ} 24^{\prime} 29^{\prime \prime} \mathrm{E}, 84 \mathrm{~m}\right.$ a.s.l.) covers an area of 4.82 ha, while lake S ( $53^{\circ} 22^{\prime} 57^{\prime} \mathrm{N}, 1^{\circ} 23^{\prime} 58^{\prime} \mathrm{E}, 86 \mathrm{~m}$ a.s.l.) is much smaller (2.46 ha). At both lakes the samples were taken from the edge of floating mat with plant association Rhynchosporetum albae Koch 1926, dominated by Rhynchospora alba (L.) Vahl and Sphagnum fallax (Klinggr.) Klinggr. A detailed description of the plant communities is given in SENICZAK (2011b).

Pools K (49 $26^{\prime} 15^{\prime \prime} \mathrm{N}$; $19^{\circ} 54^{\prime} 25^{\prime \prime} \mathrm{E}, 650 \mathrm{~m}$ a.s.1.) and LP $\left(49^{\circ} 25^{\prime} 47^{\prime \prime} \mathrm{N}\right.$; $19^{\circ} 42^{\prime} 50^{\prime \prime}$ E, $650 \mathrm{~m}$ a.s.1.) were small (ca. $2 \mathrm{~m}^{2}$ each). Their edges were formed by the plant association Eriophorum vaginatum-Sphagnum fallax Hueck 1928. At pool K, $95 \%$ of the investigated area was covered by S. fallax, while $5 \%$ by Eriophorum angustifolium Honck. At LP, about $10 \%$ were covered by E. angustifolium, $60 \%$ by S. fallax, and $30 \%$ by Polytrichum strictum Brid.

\section{Water analyses}

For water analyses, $3 \mathrm{dm}^{3}$ of water were taken from each body of water at a distance of $2 \mathrm{~m}$ from the shore. Water was analysed in the authorized Laboratory of Environmental Protection (Naftobazy Baza Paliw No. 2) in Nowa Wieś Wielka. The measured parameters and used methods are given in Table 1.

\section{Mite analyses}

From the edges of the lakes and pools, samples of Sphagnum mosses (each 100 $\mathrm{cm}^{2}$ in area and $5 \mathrm{~cm}$ in depth) were taken in replicates of 10 in spring in $2006(\mathrm{O}, \mathrm{S})$ and 2008 (K, LP). The mites were extracted in Tullgren funnels and preserved in $70 \%$ ethanol. The names of species and their systematics follow WeigmanN (2006).

The basic statistical analyses included the minimum, maximum, and mean values. For the other statistical analyses, the values were log-transformed $\ln (x+1)(B E R-$ THET \& GERARD 1965; McDonald 2009; ŁoMNICKI 2010). Normality of the distribution was tested with the Kolmogorov-Smirnov test, while the equality of variance in 
Table 1. Physicochemical parameters of water in the studied water bodies: Lake Okonek (O), Lake Stręszek (S), pool in Kaczmarka bog (K), and pool in Łysa Puścizna bog (LP)

\begin{tabular}{llrrrr}
\hline Parameter & Method & \multicolumn{3}{r}{ Lake } & \multicolumn{2}{r}{ Pool } \\
\cline { 3 - 6 } & & $\mathrm{O}$ & $\mathrm{S}$ & $\mathrm{K}$ & $\mathrm{LP}$ \\
\hline $\mathrm{pH}$ & pH meter, PN-90/C-04540.01 & 4.7 & 4.5 & 4.0 & 4.5 \\
Conductivity $(\mu \mathrm{S} / \mathrm{cm})$ & PN-EN 27888:1999 & 44.5 & 42.1 & 175.0 & 140.0 \\
Colour $\left(\mathrm{mgPt}^{\prime} / \mathrm{dm}^{3}\right)$ & PN-EN ISO7887 & 20.0 & 15.0 & 60.2 & 42.4 \\
$\mathrm{COD}\left(\mathrm{mgO}_{2} / 1\right)$ & PN-74/C-04578.03 & 21.6 & 19.1 & 126.0 & 114.2 \\
BOD $_{5}\left(\mathrm{mgO}_{2} / 1\right)$ & PN-EN 1899-1:2002, PN-EN 1899-2:2002 & 1.1 & 1.0 & 5.8 & 5.4 \\
Chlorides $(\mathrm{mg} / 1)$ & PN-75/C-04617.02, PN-ISO 9297:1994 & 17.2 & 17.2 & 42.9 & 33.0 \\
Sulphates $(\mathrm{mg} / 1)$ & PN-74/C-04566.09 & 8.2 & 4.9 & 3.7 & 4.5 \\
Total phosphorus $(\mathrm{mg} / 1)$ & PN-88 C-04537/04, PN-EN 1189:2000 & 0.01 & 0.01 & 0.30 & 0.05 \\
Total iron $(\mathrm{mg} / 1)$ & PN-ISO 6332:2001 & 0.2 & 0.3 & 1.9 & 2.0 \\
\hline
\end{tabular}

different samples, with the Levene test. The assumption of normality or equality of variance was not met, so the non-parametric Kruskal-Wallis test was used, followed by the Mann-Whitney $U$ test. Statistical calculations were carried out with STATISTICA 8.0 software.

\section{RESULTS}

All the studied bodies of water had acid $\mathrm{pH}$, but differed in most other physicochemical parameters, which were usually higher in pools than in lakes (Table 1). For example, conductivity, colour, chemical oxygen demand (COD), and biological oxygen demand $\left(\mathrm{BOD}_{5}\right)$ were several-fold higher in $\mathrm{K}$ and $\mathrm{LP}$ than in $\mathrm{O}$ and $\mathrm{S}$. Total phosphorus concentration was relatively low in lakes $\mathrm{O}$ and $\mathrm{S}$, but it was 5 -fold higher in pool LP, and as many as 30 -fold higher in pool K. Also total iron concentration was 10-fold higher in pools than in lakes, and the concentration of chlorides was several-fold higher in pools, but the level of sulphates was the highest in lake $\mathrm{O}$ and lowest in pool $\mathrm{K}$.

The analyses of acarofauna were based on 28306 mites, obtained from a total of 40 samples, including 28059 oribatid mites (6856 juveniles), belonging to 41 species. The Oribatida dominated among mites, making up more than $95 \%$ of them, whereas the second most abundant were 'other Acari', represented mostly by Prostigmata, and the least abundant group were Mesostigmata (Table 2).

When comparing the lakes with pools, there were no differences in the total abundance of total mites and the Oribatida but the species diversity of Oribatida was higher at pools than at lakes. The highest abundance of total mites and the Oribatida, 
Table 2. Abundance $\left(A\right.$, in $10^{3}$ individuals $\left./ \mathrm{m}^{2}\right)$ of some groups of Acari, number of species $(S)$ and Shannon index $\left(H^{\prime}\right)$ of Oribatida in Lake Okonek (O), Lake Stręszek (S), pool in Kaczmarka bog $(\mathrm{K})$, and pool in Łysa Puścizna bog (LP). SD = standard deviation. Superscripts denote significant differences ( $p \leq 0.05$ ): (a) between $\mathrm{O}$ and $\mathrm{S}, \mathrm{K}, \mathrm{LP}$; (b) between $\mathrm{S}$ and $\mathrm{K}, \mathrm{LP}$; (c) between $\mathrm{K}$ and LP

\begin{tabular}{|c|c|c|c|c|c|c|}
\hline \multirow{2}{*}{ Body of water } & \multicolumn{4}{|c|}{$A$ mean \pm SD and range } & \multirow{2}{*}{\multicolumn{2}{|c|}{$\begin{array}{ll}S & H \\
\text { Oribatida }\end{array}$}} \\
\hline & Total Acari & Oribatida & Mesostigmata & Other Acari & & \\
\hline Lake O & $\begin{array}{c}124.7 \pm 0.7 \\
36.7-315.6\end{array}$ & $\begin{array}{c}124.1 \pm 0.7 \\
36.2-312.0\end{array}$ & $\begin{array}{c}0.1 \pm 0.1 \\
0.0-0.4\end{array}$ & $\begin{array}{c}0.5 \pm 0.5 \\
0.0-3.2\end{array}$ & 21 & 0.651 \\
\hline Lake S & $\begin{array}{l}34.7^{\mathrm{a}} \pm 0.5 \\
14.0-64.0\end{array}$ & $\begin{array}{l}34.4^{a} \pm 0.5 \\
13.9-63.7\end{array}$ & $\begin{array}{c}0.3^{\mathrm{a}} \pm 0.3 \\
0.0-1.5\end{array}$ & 0.0 & 14 & 0.876 \\
\hline Pool K & $\begin{array}{c}97.3^{b} \pm 0.3 \\
59.6-142.5\end{array}$ & $\begin{array}{c}96.9^{b} \pm 0.3 \\
57.9-142.5\end{array}$ & $0.0^{\mathrm{b}}$ & $\begin{array}{l}0.4 \pm 0.4 \\
0.0-2.0\end{array}$ & 16 & 1.139 \\
\hline Pool LP & $\begin{array}{c}26.4^{\mathrm{ac}} \pm 0.3 \\
15.7-41.5\end{array}$ & $\begin{array}{c}25.2^{\mathrm{ac}} \pm 0.3 \\
13.7-40.9\end{array}$ & $\begin{array}{c}0.0^{\mathrm{ab}} \pm 0.1 \\
0.0-0.4\end{array}$ & $\begin{array}{c}1.1^{\mathrm{bc}} \pm 0.5 \\
0.0-2.3\end{array}$ & 25 & 1.851 \\
\hline
\end{tabular}

and their lowest species diversity were observed at lake O, while their lowest abundance and highest diversity was recorded at pool LP. Most oribatid species were not abundant and only 13 of them had dominance indices above $1 \%$.

The species structure varied between the studied bodies of water (Table 3). Although species structure of Oribatida was similar at both lakes, there were some differences between lakes and pools, as well as between both pools. In both lakes, the most abundant species was Limnozetes foveolatus $(D>80 \%)$, and relatively abundant $(D \geq 1)$ were: Hydrozetes longisetosus, Limnozetes ciliatus, Punctoribates sellnicki, and Trhypochthonius nigricans. In contrast, these species were infrequent or absent at the edges of pools of Orawa-Nowy-Targ Basin, while in turn some other Oribatida, which were absent or infrequent at the lakes, were abundant at pool edges. Interestingly, the compared pools differed significantly in species structure of Oribatida. At pool K, most abundant was Trimalaconothrus maior $(D>50 \%)$; abundant was also Hydrozetes octosetosus $(D=27 \%)$ and relatively abundant were $H$. lacustris and Limnozetes foveolatus. At pool LP, most abundant was Trimalaconothrus foveolatus $(D>40 \%)$, and relatively abundant were $T$. maior, Hydrozetes lacustris, and several species that were absent or very infrequent at the other bodies of water, like Oppiella nova, Nothrus pratensis, and Mucronothrus nasalis. Based on the species list of NiedBata \& Olszanowski (2008), Liochthonius furcillatus and Cultroribula berolina are new to the Polish fauna. 


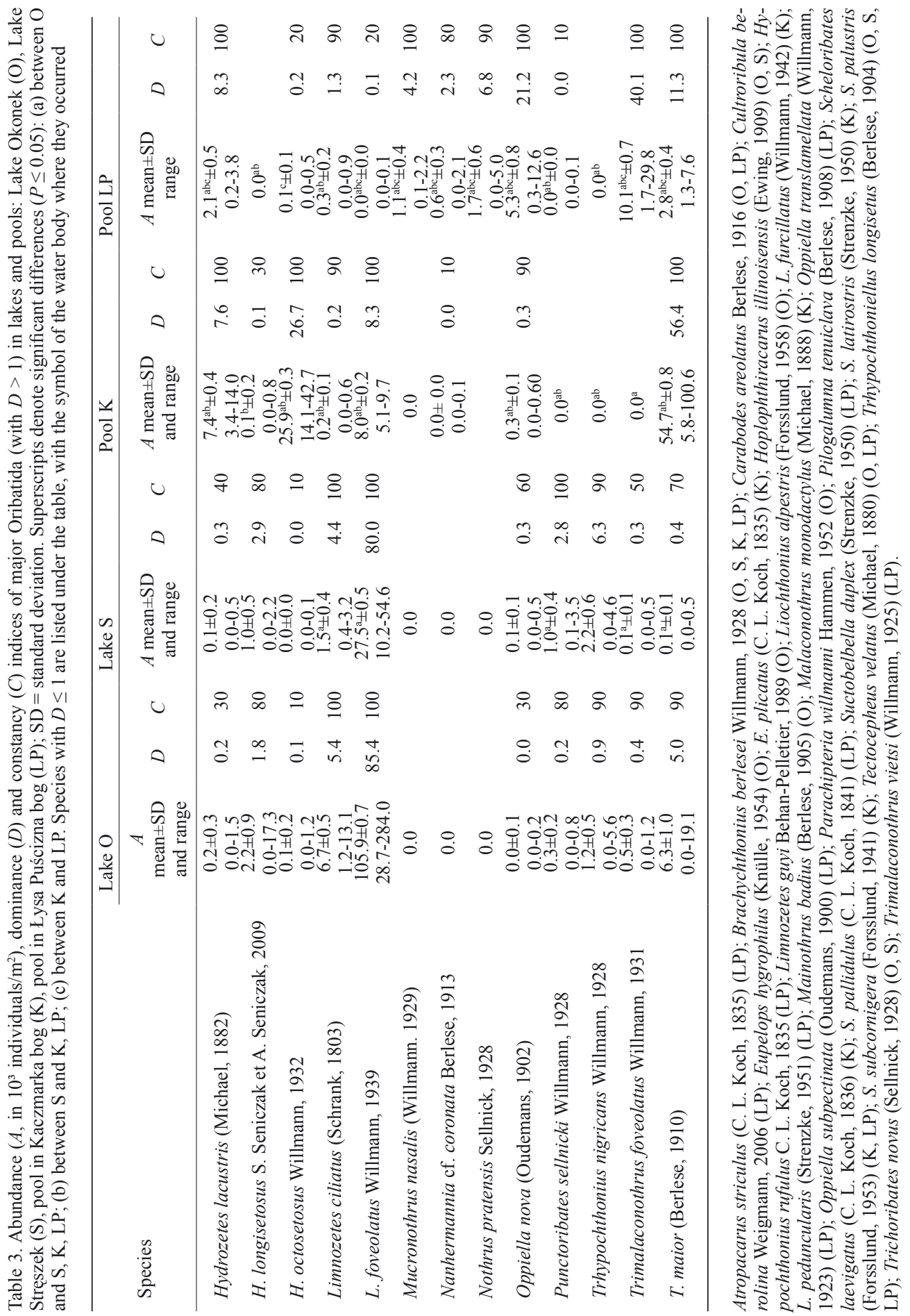




\section{DISCUSSION}

The studied bodies of water represent different stages of succession, which can partly explain the differences in their physicochemical parameters, plant associations, and species richness and composition of Oribatida. Dystrophic lakes, like O and S studied here, are slowly overgrown (on a scale of centuries) by the Sphagnum mat, being gradually replaced by bog vegetation. Then in some bogs, like in those of Orawa-Nowy-Targ Basin, small pools may be newly formed by, e.g., peat cutting (Rydin \& JegLum 2006). In the protected bogs surrounding lakes $\mathrm{O}$ and $\mathrm{S}$, conditions are close to natural, while the bogs in Orawa-Nowy-Targ Basin are subject to drainage because of peat exploitation (Kaczmarka) and pine tree planting (Łysa Puścizna) (MisTrZaK et al. 2011).

All the studied bodies of water were acidic, partly due to a well-developed Sphagnum mat surrounding them, as many peat mosses are known to decrease water pH very effectively (RYDIN \& JEGLUM 2006). However, many other parameters, like water conductivity, colour, COD, and BOD5, were several-fold higher in pools $\mathrm{K}$ and LP than in lakes $\mathrm{O}$ and S. Higher conductivity can be explained by more advanced plant succession (RusiŃSKA et al. 2009) and by bog drainage (BANAŚ \& Gos 2004). Bog drainage also leads to an increase in humic substances, which are related to darker water colour and decreased oxygen content (RYDIN \& JEGLUM 2006). Similar water parameters, including high conductivity, colour, chlorides and iron concentration, were found in a peat pond located in an exploited bog, Bagno Chlebowo (SENICZAK 2011b).

The abundance of mites, as well as of Oribatida, did not differ between lakes and pools. However, the species diversity of Oribatida was higher at the edges of pools than at lake edges, which can be related to more advanced plant succession (SENICZAK 2011b). There are no comparative data on oribatid communities from these bog pools, but e.g. at the lakes and ponds in Tuchola Forest (Bory Tucholskie, northern Poland), species diversity increased with plant succession (SENICZAK 2011b) and was the highest at the edges of Lake Łyse, which was at the most advanced stage of succession, and the Shannon index $\left(H^{\prime}\right)$ was even higher there (2.23) than in the present study.

At the studied lakes and pools, differences in species structure of Oribatida were observed. At the edges of lakes $\mathrm{O}$ and S, Limnozetes foveolatus dominated $(D>80 \%)$, like at the edges of most other bodies of water in northern Poland (SENICZAK et al. 2006; SENICZAK 2011a, b). This species clearly prefers water-saturated substrate and acid reaction (Behan-Pelletier 1989; Behan-Pelletier \& Bisset 1994; Donaldson 1996; SENICZAK 2011b), being very abundant at the margins of the Sphagnum mat, and is often accompanied by L. ciliatus (e.g. DonALDSOn 1996; SENICZAK et al. 2006; SENICZAK 2011b). Both Limnozetes spp. seem to be very sensitive to human disturbance. In northern Poland their abundance was low at the edges of bogs affected by bog drainage and spruce planting (Kurze Grzędy), and by peat mining (Bagno Chlebowo) (SENICZAK 2011b). Also in Finland the abundance of L. ciliatus decreased after bog amelioration (MARKKULA 1986a, b). This can probably explain the low abundance of Limnozetes spp. at the bogs of Orawa-Nowy-Targ Basin. 
The other aquatic genus, Hydrozetes, was represented at the study lakes most abundantly by $H$. longisetosus, like at most of dystrophic lakes and ponds in northern Poland (SENICZAK 2011b,c), while 2 other species, H. lacustris and H. octosetosus, were far less abundant. In contrast, at the edges of bog pools, most abundant was $H$. octosetosus (K) or H. lacustris (LP), while H. longisetosus was infrequent at pool $\mathrm{K}$ and absent from pool LP (MistrZAK et al. 2011). Hydrozetes longisetosus seemed to avoid bogs disturbed by human activity, and it was also absent from bogs destroyed by drainage and peat exploitation in northern Poland (SENICZAK 2011b, c).

Trimalaconothrus spp., like Limnozetes spp., require aquatic and acidic conditions, but tolerate human-disturbed habitats, as they were most abundant oribatids at the pools of Orawa-Nowy-Targ Basin. Trimalaconothrus maior was most abundant at pool K, while $T$. foveolatus dominated at pool LP. The latter species tolerates a wider range of humidity than T. maior and can be found in drier conditions (STARÝ 1988; KeHL 1997; SENICZAK 2011b).

Based on the oribatid mite communities, bog LP seems to be more disturbed by drainage than bog K. At the latter bog, the abundance of the aquatic Limnozetes and Hydrozetes spp. was far lower than at LP, and Trimalaconothrus foveolatus was more abundant than T. maior. Moreover, the generalists, like Oppiella nova, became more abundant. Similar observations were made in Finland, where after bog drainage, the hydrophilic species have decreased, while the habitat generalist, Oppiella nova, greatly benefited (MARKKULA 1986a, b).

\section{REFERENCES}

BANAŚ K., Gos K. 2004. Effect of peat-bog reclamation on the physico-chemical characteristics of the ground water in peat. Pol. J. Ecol. 52: 69-74.

Behan-Pelletier V. M. 1989. Limnozetes (Acari: Oribatida: Limnozetidae) of northeastern North America. Can. Ent. 121: 453-506.

Behan-Pelletier V. M., Bisset B. 1994. Oribatida of Canadian peatlands. Mem. Entomol. Soc. Can. 169: 73-88.

Berthet P., Gerard G. 1965. A statistical study of microdistribution of Oribatei (Acari). Part I. The distribution pattern. Oikos 16: 214-227.

Borcard D., Geiger W., Matthey W. 1995. Oribatid mite assemblages in a contact zone between a peat-bog and a meadow in the Swiss Jura (Acari, Oribatei): influence of landscape structure and historical processes. Pedobiologia 39: 318-330.

Donaldson G. M. 1996. Oribatida (Acari) associated with three species of Sphagnum at Spruce Hole Bog, New Hampshire, U.S. Can. J. Zool. 74: 1713-1720.

ERICKSON J. M. 1988. Fossil oribatid mites as tools for Quaternary paleoecologists: preservation quality, quantities, and taphonomy. Bull. Buffalo Soc. Nat. Sci. 33: 207-226.

ERICKSON J. M., Platt R. B. JR. 2007. Oribatid mite studies. In: Encyclopedia of Quaternary science (Elias S., Ed.), pp. 1547-1566, Elsevier, London.

KeHL C. 1997. Ecology of Malaconothroidea (Acari, Oribatida) in Northeast German mires. Abh. Ber. Naturkundemus. Görlitz 69: 11-18.

KURIKI G. 2008. The life cycle of Limnozetes ciliatus (Schrank, 1803) (Acari: Oribatida). J. Acarol. Soc. Jpn. 17: 75-85. 
ŁoMNICKi A. 2010. Wprowadzenie do statystyki dla przyrodników [Introduction to statistics for biologists]. PWN, Warszawa (in Polish).

MarkKula I. 1986a. Comparison of the communities of oribatids (Acari: Cryptostigmata) of virgin and forest ameliorated pine bogs. Ann. Zool. Fenn. 23: 33-38.

MARKKULA I. 1986b. The subfossil oribatids as indicators of the faunal changes in forest-ameliorated peatlands. University of Joensuu, Publications of Karelian Institute 79: 81-86.

McDonald J. H. 2009. Handbook of biological statistics, 2nd ed. Sparky House Publishing, Baltimore, Maryland.

Mistrzak M., Seniczak A., Seniczak S. 2011. Hydrozetes species (Acari, Oribatida) at bog ponds and pools in the Tatra National Park and Orawa-Nowy-Targ Basin (Kotlina Orawsko-Nowotarska) in southern Poland. Biological Lett. 48: 139-145.

Niedbala W., Olszanowski Z. 2008. Roztocze (Acari). In: Fauna Polski. Charaterystyka i wykaz gatunków [Fauna of Poland. Characteristics and list of species] (Bogdanowicz W., ChudzICKa E., Pilipuk I., Skibińska E., Eds.), vol. 3, pp. 11-14, Muzeum i Instytut Zoologii PAN, Warszawa (in Polish).

Popp E. 1962. Semiaquatile Lebensräume (Bülten) in Hoch- und Niedermooren. 2 Teil. Die Milbenfauna [Semi-aquatic habitats (hummocks) of raised bogs and fens. (2nd Part. The mite fauna)]. Int. Rev. Ges. Hydrobiol. 47: 533-579 (in German).

Popp E. 1970. Communities of moss mites (Oribatei) in a gradient area. Oikos 21: 236-240.

Presthus-Heggen M., Birks H. H., Anderson N. J. 2010. Long-term ecosystem dynamics of a small lake and its catchment in west Greenland. The Holocene 20: 1207-1222.

RAJSKI A. 1970. Autecological-zoogeographical analysis of moss mites (Acari, Oribatei) on the basis of fauna in the Poznań Environs. Part III. Acta Zool. Crac. 15: 161-250.

Rusińska A., Górski P., GąbKa M., Stebel A., Fudali E., Szczepański M., Rosadziński S., Wolski G., Pisarek W., Zubel R., Staniaszek-Kik M., Pawlikowski P., Wilhelm M., Salachna A., ZaLewSKA-GAtosz J. 2009. Bryoflora of the spring fen 'Makaty' in north western Wielkopolska region. Rocz. AR w Poznaniu, Botanika-Steciana 13: 155-166.

Rydin H., Jeglum J. K. 2006. The biology of peatlands. Oxford University Press.

SeniczaK A. 2011a. Ecology of Hydrozetes Berlese, 1902 (Acari, Oribatida) at various water bodies near Bydgoszcz (northern Poland). Biological Lett. 48: 185-192.

SenicZAK A. 2011b. Mites (Acari) of the shores of forest lakes and ponds in northern Poland, with species analysis of Oribatida. Uniwersytet Technologiczno-Przyrodniczy, Bydgoszcz.

Seniczak A. 2011c. Oribatid mites (Acari, Oribatida) and their seasonal dynamics in a floating bog mat in Jeziorka Kozie Reserve, Tuchola Forest (Poland). Biological Lett. 48: 3-11.

Seniczak A., Seniczak S., Nowicka A. 2006. Roztocze (Acari) strefy brzegowej dwóch jezior śródleśnych, o różnej jakości wody, w Borach Tucholskich [The mites (Acari) of the water edge of two forest ponds with different water quality in the Tuchola Forest]. Zesz. Nauk. ATR w Bydgoszczy, Zootechnika 36: 31-38 (in Polish).

Solнøy T. 2001. Oribatid mites. In: Tracking environmental change using lake sediments, vol. 4, Zoological indicators (SMol J. P., BiRKS J. B., LASt W. M., Eds), pp. 81-104, Kluwer Academic Publishers, Dordrecht, The Netherlands.

StarÝ J. 1988. Pancírníci (Acari: Oribatida) některých vrchovišt' na Šumavě, jižní Čechy [Moss mites (Acari: Oribatida) of some moor in Sumava, South Bohemia]. Sbor. Jihočes. Muz. v Čes. Budějovicích Přír. Vědy 28: 99-107 (in Czech).

StrenzKe K. 1952. Untersuchungen über die Tiergemeinschaften des Bodens: Die Oribatiden und ihre Synusien in den Böden Norddeutschlands [Studies on the animal communities in the soil: The Oribatida and thier associations in the soils of northern Germany]. Zoologica 104: 1-173 (in German).

Weigmann G. 2006. Hornmilben (Oribatida) [Oribatid mites (Oribatida)]. Die Tierwelt Deutschlands, vol. 76, Goecke and Evers Keltern, 1-520 (in German). 